\title{
Cutting-edge Innovations in Cardiac Health: Galvanic Insights from a Clinician-Scientist, Dr. Benjamin Hibbert
}

\author{
Faizan Khan ${ }^{1}$, Phillip Staibano², Mimi Xiaoming Deng² ${ }^{2}$ Linda Yi Ning Fei ${ }^{2}$ \\ ${ }^{1}$ Clinical Epidemiology, Ottawa Hospital Research Institute, Ontario, Canada \\ ${ }^{2}$ Faculty of Medicine, University of Ottawa, Ontario, Canada
}

ABSTRACT

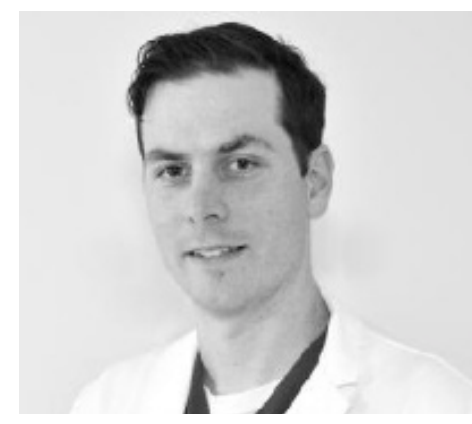

Dr. Benjamin Hibbert, MD, PhD, FRCPC is an interventional cardiologist, an assistant professor, as well as the director of the Vascular Biology and Experimental Medicine Laboratory at the University of Ottawa Heart Institute. With a focus on performing revolutionary bench-to-bedside research, Dr. Hibbert's research interests include the development of novel cardiac biomarkers, elucidating the mechanisms that underlie pathological arterial remodeling in transplant vasculopathy, and the pharmacodynamics of adjuvant antiplatelet and antithrombotic agents in cardiac disease. We had the privilege of speaking with Dr. Hibbert about his career path, research experiences, and perspectives on the importance of the clinician-investigator program in training the oncoming generation of clinician-scientists. We also discuss the burgeoning field of meta-research and the role that methodological scrutiny has on the development of clinical guidelines and evidence-based medicine. We hope that this interview inspires the next generation of clinicians to pursue clinical investigator programs (CIP) and incorporate academia into their medical practice.

\section{RÉSUMÉ}

Dr Benjamin Hibbert, MD, PhD, FRCPC, est un cardiologue interventionniste, un professeur adjoint, ainsi que le directeur du Laboratoire de biologie vasculaire et de médecine expérimentale à I'Institut de cardiologie de I'Université d'Ottawa (ICUO). En se concentrant sur la recherche du laboratoire-au-chevet révolutionnaire, les intérêts de recherche clinique et de sciences de base de Dr Hibbert incluent le développement de biomarqueurs cardiaques nouveaux, l'élucidation des mécanismes sousjacents le remodelage artériel pathologique lors de la vasculopathie de transplantation, et les pharmacodynamiques d'agents antiplaquettaires et antithrombotiques adjuvants dans les maladies cardiaques. On a eu le privilège de discuter avec Dr Hibbert sur son parcours professionnel, ses expériences de recherche, et les perspectives sur l'importance du programme du clinicienchercheur pour l'entrainement de la génération future de cliniciens-scientifiques. On a aussi discuté du champ naissant de metarecherche et le rôle que l'examen minutieux a sur le développement de lignes directrices et la médecine factuelle. On espère que cette entrevue inspire la prochaine génération de cliniciens à poursuivre des programmes de clinicien-chercheur (PCC) et incorporer le milieu universitaire dans leur pratique médicale.

Tell us a bit about your academic background and your current professional roles.

I completed all my education and training at the University of Ottawa: undergraduate degree in Biology/Biotechnology, medical school, as well as my internal medicine and cardiology residency training. During my internal medicine training, I started my $\mathrm{PhD}$ in biochemistry as part of the clinicianinvestigator program (CIP), which I completed alongside my cardiology training. I then completed a two-year fellowship in interventional cardiology at the University of Ottawa Heart Institute (UOHI). So, now I am a clinician-scientist.
My clinical responsibilities include critical care cardiology, percutaneous coronary intervention, and treating valvular and congenital heart diseases with transcatheter technology. My research focus is on vascular biology, specifically working on translational projects - trying to take basic science insights and move them into early clinical practice.

How did you choose a clinician-scientist career in cardiology?

I am from a small town, and so, when I got into medical school, I thought I was going to go into family medicine because

Keywords: Interview; Cardiology; Translational Research; Meta-research; Biochemistry 
that was the kind of doctor that I knew. I think this is true of anything - there is a tremendous amount of role modelling in life. In medical school, I loved the study of cardiovascular medicine. I had the opportunity to work with excellent interventional cardiologists, such as Drs. Christopher Glover, Michael Froeschl, Ed O'Brien, and Marino Labinaz, and I have taken little bits of all of them that I admired and have incorporated them into my current clinical and academic work. I benefited from being at the right place at the right time, which helped me find something that I was really passionate about. During my undergraduate degree, I got an opportunity through the NSERC scholarship to work in the laboratory of professor Vance Trudeau, doing research on goldfish endocrinology. I had a phenomenal experience and that is when I got the bug for research. When I started medical school, I realized that I missed doing research, and wanted to continue it. So, in first year of medical school, I started working in the laboratory of Dr. Ed O'Brien, an interventional cardiologist at the $\mathrm{UOHI}$ who does vascular biology research. He was a rare hybrid in terms of a clinician who did basic science research. During my medical training, as I spent more time doing research, I realized that I really wanted to have this as part of my career-and that is when I learned about the CIP.

What factors do you think students should take into account as they contemplate pursuing a clinician-investigator program (CIP) alongside their medical residency training?

I think the clinician-investigator program (CIP) is the only way to train a clinician-scientist, period. I think training medical students in research methodologies so early on in their training does them a disservice, not because the skill set that you learn is not applicable, but I genuinely worry about picking a topic and researching it without actually knowing what the clinical practice is like in that particular field. If you train people too early, there will be more attrition and they will likely change fields. Additionally, clinical training is getting so long now that building CIP training longitudinally throughout enables people to obtain their graduate degrees without spending too many additional years, which may otherwise discourage people from pursuing academia. The advantage of CIP is that when you enter the program, you have chosen the speciality of medicine (e.g., general surgery, cardiology, etc.) that you want and your research training and development is focused around your own clinical practice. I would love to know what percentage of students completing the combined $\mathrm{MD} / \mathrm{PhD}$ program actually end up working in the clinical field in which they did their research training. I think there is a huge advantage, both in terms of career development and applied research when you study the field that you are going to work in as a clinician.

As I mentioned earlier, during my undergraduate degree, my research focused on goldfish endocrinology. While llearned the research skills at that time, my manuscripts on the complexities of the goldfish pituitary gland are not necessarily helping to develop my current career. I think the CIP is perfect in that it provides protected time for longitudinal research during your clinical training - that is exactly how my current professional life is structured. I think the CIP program does mimic what your life is going to look like if you become a clinician- scientist. You will be doing research while you are doing clinical workthat is a beautiful way to prepare residents to transition from trainee to assistant professor, which is exactly the goal of training clinician scientists: to do applicable translational research. I credit Dr. Jonathan Angel for leading the CIP at the University of Ottawa at that time, and I hope the university continues to support this training program because I think that is the only way you will get people that genuinely end up doing the kind of work required to become a proficient and productive clinician-scientist.

Did you gain experience with clinical research methodologies during your CIP, and do you find yourself using both sets of skills as a clinician-scientist?

I do both clinical and basic science research as a practicing clinician-scientist. I got a lot of exposure to clinical research methodologies during my residency training, as I collaborated in clinical trials and observational studies. Although I didn't get any formal training in clinical research methodologies, which would be nice to have, I did get a lot formal training in biochemistry. So when I was making the decision to pursue the CIP, I thought it was more important to get trained in bench-top research because that is not something you can pick up on the fly, whereas I thought the clinical research methodology is much more learnable. Also, at that time, I was interested in basic science research-it takes a lot more time and so I wanted to spend a lot of my protected time on that. And I'm glad I did. 
You have done work in endothelial progenitor cells and their role in arterial repair. This is a medical innovation that has the ability to revolutionize cardiology practice. Would you be able to speak to the process in seeing these revolutionary laboratory findings turn into clinical trials and how they will eventually find their way into clinical practice?

I think you are going to be disappointed with this answer. I don't think any of the stem cell or progenitor cell research (in cardiology) is going to reach prime time. This speaks to difference between the left and the right hands not talking to each other. Something I realized very early in the cardiology field is that a lot of these stem cell innovations work very well in healthy volunteers, but the reality is that when we look at stem cells from older patient populations, they are not as functional. The engraftment is poor, therapeutic benefit is less, and you get fewer of the cells. This is a major limitation to therapy and researchers are trying to find a work-around to this. This field has been going on for a long time and I think lot of the luster has been worn off. As part of my training, I did a lot of preclinical work and I realized very early that it's very difficult to get enough cells to treat a patient and it's difficult to enroll patients in clinical trials. We have very good therapies for these patient populations that don't necessarily require stem cell-based therapies. I'll go out on a limb and say ten years from now, we are still not going to be treating patients with progenitor stem cells for cardiovascular disease. I've actually moved away from that line of work and I think it's important that as scientists we are realistic about evaluating the evidence and the data. When we realize a therapy is not working, we move on. I see it too often that people marry their careers to ideas that are clearly not going to translate but they hammer on it without making significant progress. I have started collaborating with industry on new technologies in structural heart disease. And I have been impressed working with these companies and engineers and I actually think there's a lot that academic research can learn from industry: the willingness to abandon ideas that aren't working and the willingness to explore ideas that might seem infeasible or improbable. That's how you truly make innovations and discoveries and impact in medicine. All too often I see in academia people married to hypotheses and concepts, unwilling to be flexible and truly evaluate the evidence. So, one of the things that I have started doing in my career is working with industry to really try to do these early procedures and early innovationswe'll be publishing some interesting first in-human work looking at novel therapies for heart failure soon. I think I'll be working a lot more with industry to try and leverage the knowledge base and the engineering expertise and really move the needle in terms of translational work.

How would you define medical innovations?

I think some of the most fascinating innovations are the use of technology or reapplying technology or insights that we already have to different problems. Recently, for example, Dr. Pietro di Santo (cardiology and a PhD Epidemiology trainee) and I ran a clinical trial to assess blood flow in the hand. This is commonly done in clinical practice to make sure arteries are good in the hand before we either put tubes in them or we take them for bypass grafts for surgery. We realized that we could use something as easy as photoplethysmography with an iPhone to do what we try to clinically in looking at the hand much more accurately. We published this randomizedcontrol trial in the Canadian Medical Association Journal (1) demonstrating this concept and now we are moving this to the next level. Our goal is to use this iPhone technology to select patients for use of arterial conduits and bypass. This is an example of applying a readily available technology to a clinical problem that we encounter in practice on a regular basis.

I alluded to earlier we have been working a lot with industry. We understand that differences in the pressures of the chambers of the heart can be important for patients' symptoms. Therefore, we have been working with Edward Lifesciences to look at new forms of shunting technology to decompress the left atrium for patients with heart failure. We are working to develop a new type of shunting procedure to help these patients. There is nothing novel about the concept of intra-cardiac shunts, but the innovation is in how they are delivered, what devices are used, what occurs in terms of the healing of these devices, and how it impacts patient care. I do see, even in the research that we do here, really innovative and novel approaches to problems by simply applying the technology and knowledge that we already have and leveraging that to treat patients that we see everyday. From a bench-to-bedside approach, we need to do a lot more of that. There are lots of interesting basic science insights that occur, but the reality is, the people who are doing that basic science research don't really understand the clinical problem and clinical context, so they are unable to see that through to translation. And that's where clinician scientists come by providing that clinical insight and context. What I see in the future for this kind of work, if we want to be successful and capitalize on the investment 
that we make, is a lot more collaborative teamwork between basic scientists, engineers, clinician-scientists, and clinicians to move this forward. We still work too often in silos; I think you'll see a lot more collaborations moving forward especially if we want to be successful in advancing medical technologies.

Meta-research, or research on research, is revolutionizing research practices and how we evaluate scientific methodologies. Can you tell us about some of your current work in meta-research?

One of the things that l am particularly proud of is the work of Dr. Dan Ramirez, who did his Masters in epidemiology. One of the things that often gets overlooked is that science is not perfect, science is dirty. We like to think that papers in high-impact journals are high quality and we like to think that conclusion from our scientific work are immutable. One of the things we have learned is that there is a lot of really poorly done science published in excellent journals. We may either reject therapies because of poorly done work, or we embrace therapy because of poorly done work. In our work published in Circulation Research (2), we found that the methodological rigour in basic science research is shockingly bad, and this is likely reflected in the reproducibility crisis that we have. Probably about $85 \%$ of the work is completely irreproducible largely due to methodological problems. We spend large proportions of our research budgets on fundamental sciences and, to be frank, the work is simply not good. There is, and has to be a lot of room for improvement. We owe a debt to society when the public provides funds for academic fundamental research that those funds get used appropriately. We have a lot of work coming out on this, highlighting how even in top journals of science, there's low quality research being done. If there's one thing we can do on the basic science front, it is this: there needs to be a revolution in terms of methodologies and how we do science. Because I think the flip side of that is, the public will wake up to it and you'll have trouble lobbying the government for funding for research if that money is not being well spent. So, that's one area that I am particularly proud of Dan and our group:we have been able to highlight some of these things and make significant contributions to the field, and I hope moving forward all of that will improve.

As students undergoing graduate and clinical studies, we are often told of the importance of maintaining a work-life balance. As a leading clinician-scientist at $\mathrm{UOHI}$, how do you manage your work-life balance?
Yeah, I don't. This is very different from my colleagues so don't take this as gospel-I worry when people strive to find "work-life balance". You always trade them off. And that's an unfortunate and hard truth to hear. On one hand, people who spend a ton of time on their personal life probably are not as productive professionally. And that's life-you have only twenty-four hours in a day. On the other hand, people who bury themselves in their professional life obviously make sacrifices at home. So, when I'm with my family, I try to focus and spend quality time with my family. When I'm working professionally, I try to be as efficient as possible. And the reality is that I sacrifice things in both realms: I don't accomplish all the professional things that I want to accomplish and I don't spend nearly as much time with my family as I want to spend. I think the concept of work-life balance is a myth. I think work and life are competing interests because they both require time. I very much doubt that there are people in the world who are supersuccessful both professionally as well as at meeting all the demands of their personal life. I have made sacrifices in terms of my hobbies, and the time I spend going out with my friends. I have really compartmentalized my life into my personal work and my family — I prioritize those two things and the reality is when my professional life gets busy, my personal life suffers and if I spend more on my personal life, then my professional productivity suffers. That balance between the two is different for everyone and people have to find what is an acceptable balance to them, but there is no true balance. There is no way to be super-successful at both-at least l've never met anyone who is.

Would you be able to provide any advice for students who are interested in pursuing a career in general or interventional cardiology?

If you want to be a community interventional cardiologist and put stents in from morning to afternoon, call it a day and occasionally do a STEMI call, I don't think it's that different than any other clinical job that's out there. There are lot of hardworking doctors out there putting in a lot hours,work hard to do really good for their patients. However, if you want to be an academic interventional cardiologist, general surgeon, thoracic surgeon, or pediatrician for example, I think you have to recognize that that is a commitment, and that commitment is paid in time. You may get through your training, but if you're not willing to put the hours in, you're simply not going to be successful at what you do. Even putting in the hours, you are 
not necessarily guaranteed to be successful. So, if you're going to commit to this career path, you want to make sure you are willing to put in the work and the hours. I see often, people who train to become an academic fail: not because they are not capable and not because they don't have enough support, but because life happens. Again, to go back to that work-life balance: they are unable to put in the time to get the work done. I would just warn people to be honest with themselves, about what lifestyle they want, how many hours they want to work, how much they enjoy it, and how much they're willing to sacrifice for it, because you have to love it if you're going to put in huge amounts of hours doing something.

\section{ACKNOWLEDGEMENTS}

The authors would like to thank Dr. Hibbert for taking his valuable time to answer all of our questions.

\section{REFERENCES}

1. Santo PD, Harnett DT, Simard T, Ramirez FD, Pourdjabbar A, Yousef A, et al. Photoplethysmography using a smartphone application for assessment of ulnar artery patency: a randomized clinical trial. CMAJ. 2018 Apr;190(13) E380-E388.

2. Ramirez FD, Motazedian P, Jung RG, Santo PD, Macdonald ZD, Moreland R, et al. Methodological Rigor in Preclinical Cardiovascular Studies: Targets to Increase Reproducibility and Promote Research Translation. Circ Res. 2017 Jun;120(12):1916-26. 